\title{
High efficiency generalized transduction in Escherichia coli
}

\section{7:H7 [version 1; peer review: 2 approved, 1 approved with}

\section{reservations]}

\author{
Martin G Marinus ${ }^{1}$, Anthony R Poteete ${ }^{2}$ \\ ${ }^{1}$ Biochemistry and Molecular Pharmacology, University of Massachusetts Medical School, Worcester MA, 01605, USA \\ ${ }^{2}$ Department of Microbiology and Physiological Systems, University of Massachusetts Medical School, Worcester, MA 01605, USA
}

V1 First published: 10 Jan 2013, 2:7

https://doi.org/10.12688/f1000research.2-7.v1

Latest published: 10 Jan 2013, 2:7

https://doi.org/10.12688/f1000research.2-7.v1

\section{Abstract}

Genetic manipulation in enterohemorrhagic E. coli $0157: \mathrm{H7}$ is currently restricted to recombineering, a method that utilizes the recombination system of bacteriophage lambda, to introduce gene replacements and base changes inter alia into the genome.

Bacteriophage $933 \mathrm{~W}$ is a prophage in E. coli O157:H7 strain EDL933, which encodes the genes (stx2AB) for the production of Shiga toxin which is the basis for the potentially fatal Hemolytic Uremic Syndrome in infected humans. We replaced the st $2 A B$ genes with a kanamycin cassette using recombineering. After induction of the prophage by ultra-violet light, we found that bacteriophage lysates were capable of transducing to wildtype, point mutations in the lactose, arabinose and maltose genes. The lysates could also transduce tetracycline resistant cassettes. Bacteriophage $933 \mathrm{~W}$ is also efficient at transducing markers in E. coli K-12. Co-transduction experiments indicated that the maximal amount of transferred DNA was likely the size of the bacteriophage genome, $61 \mathrm{kB}$. All tested transductants, in both E. coli $\mathrm{K}-12$ and $0157: \mathrm{H7}$, were kanamycin-sensitive indicating that the transducing particles contained host DNA.

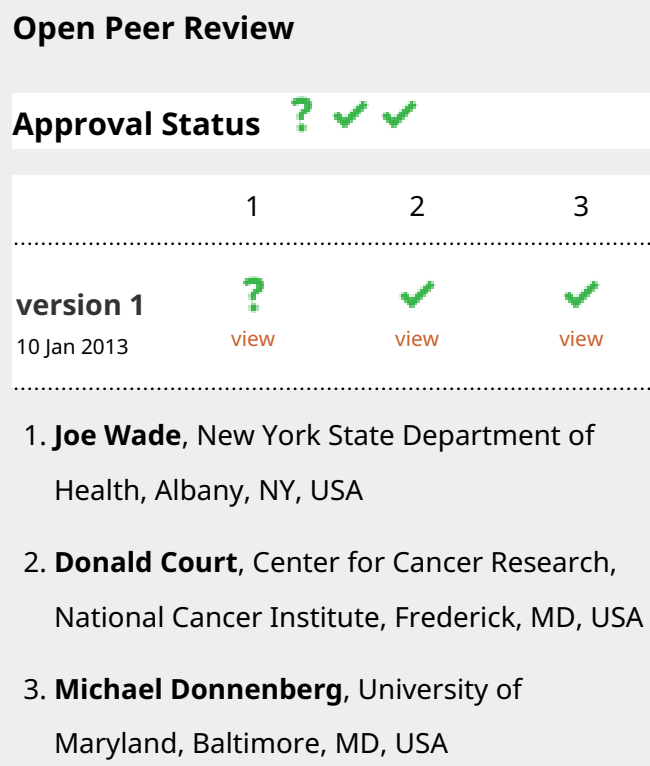

1. Joe Wade, New York State Department of Health, Albany, NY, USA

2. Donald Court, Center for Cancer Research, National Cancer Institute, Frederick, MD, USA

3. Michael Donnenberg, University of Maryland, Baltimore, MD, USA Any reports and responses or comments on the article can be found at the end of the article.

Corresponding author: Martin G Marinus (martin.marinus@umassmed.edu)

Competing interests: No competing interests were disclosed.

Grant information: This work was supported by NIH grant GM063790 to MGM.

The funders had no role in study design, data collection and analysis, decision to publish, or preparation of the manuscript.

Copyright: @ 2013 Marinus MG and Poteete AR. This is an open access article distributed under the terms of the Creative Commons Attribution License, which permits unrestricted use, distribution, and reproduction in any medium, provided the original work is properly cited. Data associated with the article are available under the terms of the Creative Commons Zero "No rights reserved" data waiver (CC0 1.0 Public domain dedication).

How to cite this article: Marinus MG and Poteete AR. High efficiency generalized transduction in Escherichia coli 0157:H7 [version 1; peer review: 2 approved, 1 approved with reservations] F1000Research 2013, 2:7 https://doi.org/10.12688/f1000research.2-7.v1 First published: 10 Jan 2013, 2:7 https://doi.org/10.12688/f1000research.2-7.v1 


\section{Introduction}

Enterohemorrhagic Escherichia coli (EHEC) serotype O157:H7 is among the leading causes of food- and water-borne illnesses affecting humans in the U.S., Europe, and Japan (for review, see Donnenberg and Whittam (2001) $)^{1}$, Kaper et al. (2004) ${ }^{2}$ and Spears et al. $\left.(2006)^{3}\right)$. These bacteria are highly infectious and ingestion of only 100-200 organisms is sufficient to trigger debilitating diarrheal disease. Although most EHEC infections resolve spontaneously after 5-10 days of abdominal cramping and bloody diarrhea, approximately $2-7 \%$ of cases progress to the potentially fatal hemolytic uremic syndrome due, in part, to the production of cytotoxic Shiga toxins which are capable of promoting kidney failure (Donnenberg and Whittam $(2001)^{1}$, Kaper et al. $(2004)^{2}$ and Spears et al. $\left.(2006)^{3}\right)$. The genes for Shiga toxin $($ st $x 2 A B)$ are located on a prophage in the late region between genes $\mathrm{Q}$ and $\mathrm{S}$ and are transcribed with the late region genes from promoter $\mathrm{P}_{\mathrm{R}}$ ' (Tyler et al. $\left.(2004)^{4}\right)$.

The most widely used genetic manipulation in EHEC is recombineering, a method that utilizes the recombination system of bacteriophage lambda, to introduce gene replacements and base changes inter alia into the genome (Murphy $(1998)^{5}$, Court et al. $\left.(2002)^{6}\right)$. A method for using the generalized transducing bacteriophage P1 in EHEC has been reported previously but it requires the construction of galactose mutant derivatives of the recipient strain (Ho and Waldor $\left.(2007)^{7}\right)$.

In EHEC strain EDL933, the $s t x 2 A B$ genes are located on prophage $933 \mathrm{~W}$, the genome size of which is $61 \mathrm{kB}$ (Penna et al. $(2001)^{8}$ ). The DNA sequence of both the prophage and free phage are known. During sequencing of the free phage genome, it was noticed that the ends of the genome could not be sequenced; the investigators interpreted this and other observations as indicating that the packaged chromosome might be terminally redundant (Plunkett et al. $\left.(2001)^{9}\right)$. Because terminal redundancy is a shared feature among generalized transducing phages, this finding suggested that bacteriophage $933 \mathrm{~W}$ might be capable of packaging host DNA and transducing genetic markers. We report here that bacteriophage $933 \mathrm{~W}$ is capable of transducing genetic markers in unmodified EHEC and E. coli $\mathrm{K}-12$ strains.

\section{Methods}

\section{Bacterial strains}

The EHEC strain used principally in this paper is KM80 (Carone et al. unpublished document), a derivative of EDL933 which lacks prophage 933W (obtained from Dr. K.C. Murphy). Derivatives of KM80 unable to utilize lactose (GM9289), arabinose (GM9290) or maltose (GM9291) were obtained after a 20 min exposure of a $10 g$ phase culture in L broth to $40 \mu$ l ethyl methane sulfonate (SigmaAldrich) per $\mathrm{ml}$ at $37^{\circ} \mathrm{C}$ followed by a $1 / 100$ dilution into broth. Aliquots of the saturated culture were plated on MacConkey Agar Base (Difco) containing lactose, arabinose or maltose to detect nonfermenting colonies. The $E$. coli $\mathrm{K}-12$ strains used were AB 1157 (thr-1 araC14 leuB6(Am) $\Delta$ (gpt-proA)62 lacY1 tsx-33 supE44(AS)

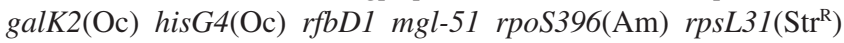
kdgK51 xylA5 mtl-1 argE3(Oc) thi-1) (Dewitt and Adelberg $\left.(1962)^{10}\right)$ (obtained from Dr. E.A. Adelberg), MM294 (endA1 hsdR17 supE44(AS) rfbD1 spoT1 thi-1) (Meselson and Yuan $(1968)^{11}$ ) (obtained from Dr. M. Meselson), GM1731 (cysG98::Tn5)
(Shaw and Berg (1979) ${ }^{12}$ ) and GM1748 (leu::Tn10) (Kleckner et al. $\left.(1975)^{13}\right) .(A m=a m b e r, A S=a m b e r$ suppressor, Oc=ochre $)$. Strains containing the $\operatorname{Tn} 5$ and Tn 10 mutations were obtained from Drs. C. Berg and N. Kleckner respectively. The composition of $\mathrm{L}$ broth and minimal medium has been described previously (Nowosielska and Marinus (2008) $)^{14}$.

\section{Bacteriophage construction, induction and transduction}

Replacement of the stx $2 A B$ genes in EDL933 by recombineering as described by Murphy and Campellone (2003) ${ }^{15}$ was carried out to yield strain GM9251. In a polymerase chain reaction containing Herculase II DNA polymerase Agilent Technologies), supplied buffer, $2 \mu \mathrm{l}$ GM1731, and primers. ggtctggtgctgattacttcagccaaaaggaacacctgtatatgTATGGACAGCAAGCGAACCG and gattacacttgttaccacataccacgaatcaggttatgcctcaTCAGAAGAACTCGTCAAGAAG (sequence in capital letters is of Tn5), a DNA fragment containing the kanamycin-resistance gene was synthesized. This fragment was electroporated into EDL933 containing pKM208, a thermosensitive plasmid bearing the bacteriophage lambda exo and bet genes (Murphy and Camellone (2003) ${ }^{15}$ ) followed by selection for kanamycin-resistant clones. These were tested further by the ability of the cells to produce infective centers on strain AB1157 (Dewitt and Adelberg $(1962)^{10}$ ) and one of these was designated GM9251.

Prophage induction was accomplished by plating $10 \mu \mathrm{l}$ of a standing overnight culture on solid medium and irradiating with $25 \mathrm{~J} / \mathrm{m}^{2}$ ultraviolet light followed by an overlay of $3.5 \mathrm{ml}$ soft agar $(0.3 \%)$ containing $300 \mu \mathrm{l}$ of a standing overnight culture of the desired strain for bacteriophage propagation. Alternatively, the desired strain was mixed with dilutions of bacteriophage lysate at $37^{\circ} \mathrm{C}$, incubated for $30 \mathrm{~min}$, and incorporated in a soft agar layer on solid medium. In both induction and bacteriophage propagation, the plates were incubated at $37^{\circ} \mathrm{C}$ overnight. The next day, the soft agar layer was scraped off, and $4 \mathrm{ml}$ of L broth or TM buffer $(10 \mathrm{mM}$ Tris- $\mathrm{HCl}, \mathrm{pH} 7.4,10 \mathrm{mM} \mathrm{MgSO}_{4}$ ) was added together with $0.15 \mathrm{ml}$ chloroform. The mixture was vortexed and left at room temperature for 10 min followed by centrifugation in a microfuge at room temperature for $2 \mathrm{~min}$ at $10,000 \mathrm{rpm}$. The supernatant was either used immediately or mixed with an equal volume of $4 \mathrm{M}$ ammonium sulfate. The bacteriophage suspension in ammonium sulfate is stable for at least one month at $4^{\circ} \mathrm{C}$ in the dark. During lysate preparation it is crucial that the temperature remain at or above $20^{\circ} \mathrm{C}$. Lysates were titered on $\mathrm{AB} 1157$.

For transduction, the recipient strain was grown standing overnight in liquid medium at $37^{\circ} \mathrm{C}$, centrifuged, and resuspended in fresh medium. The recipient strain $(100 \mu \mathrm{l})$ was mixed with varying amounts of bacteriophage lysate and $400 \mu \mathrm{l}$ fresh medium. For selection using auxotrophic markers, the mixture was spread on selective minimal medium without further incubation. For drug-resistance markers, the mixture was incubated at $37^{\circ} \mathrm{C}$ for $60 \mathrm{~min}$ before plating on antibiotic medium. The plates were incubated at $37^{\circ} \mathrm{C}$.

A $933 \mathrm{~W}$ lysogenic derivative of $E$. coli $\mathrm{K}-12$ was constructed as follows. Dilutions of a GM9251 induced lysate were mixed with a standing overnight L broth culture of strain MM294 and incubated at $37^{\circ} \mathrm{C}$ for $60 \mathrm{~min}$ and portions added to L broth-kanamycin plates 
and incubating them overnight at $37^{\circ} \mathrm{C}$. Colonies were picked into $\mathrm{L}$ broth supplemented with kanamycin and grown overnight at $37^{\circ} \mathrm{C}$. The broth cultures were diluted and $10 \mu \mathrm{l}$ portions placed onto a soft agar $(0.3 \%)$ layer containing $200 \mu \mathrm{l}$ of a standing overnight culture of AB1157 on an L broth plate. After allowing the drops to dry the plate was incubated overnight at $37^{\circ} \mathrm{C}$. A kanamycin-resistant lysogen that formed infective centers by this method was designated GM9255 and 933W phage induced from this lysogen was used in all experiments with E. coli $\mathrm{K}-12$.

\section{Results and discussion}

Initial experiments with bacteriophage $933 \mathrm{~W}$ st $x 2 A B::$ Kan were confounded by its instability. It was found that the bacteriophage was cold-sensitive and would not form plaques on indicator strains at $30^{\circ} \mathrm{C}$ but could do so at $37^{\circ} \mathrm{C}$. The lysates rapidly lost infective titer ( $>90 \%$ ) upon incubation at $4^{\circ} \mathrm{C}$ overnight. The addition of $2 \mathrm{M}$ ammonium sulfate to the lysates stabilized the titer.

The observation that the bacteriophage $933 \mathrm{~W}$ chromosome had terminal redundancy suggested that, like bacteriophage P1, it should be capable of transducing genetic markers. Strain KM80, which is derived from EDL933 and is not lysogenic for 933W, was mutagenized with ethyl methane sulfonate and the lactose, arabinose and maltose non-fermenting derivatives were isolated. These derivatives were used as recipients for transduction and, after mixing with bacteriophage from strain GM9251, were plated on minimal medium containing the appropriate carbon source. The results in Table 1 show that colonies were present on the plates with the mixture but not on plates with the recipient alone or the bacteriophage alone. Forty recombinants from each transduction were patched onto solid medium with kanamycin and all were sensitive.

A $933 \mathrm{~W}$ stx2AB::Kan lysogen (GM9255) of E. coli K-12 strain MM294 was constructed and a lysate prepared on E. coli K-12 strain GM1748 (leu::Tn10). This lysate was used to transduce strain AB1157 (Thr Ara) to tetracycline-resistance (due to the $\mathrm{Tn} 10$ ). Of the 40 recombinants tested, $100 \%$ were $\mathrm{Ara}^{+}$and $100 \%$ Thr. Given that the gene order is thr-ara-leu and that the intervals between $t h r$ and $l e u$, and $a r a$ and $l e u$, are 80 and $14 \mathrm{kB}$ respectively, the result indicates that cotransduction is possible for marker separated by $14 \mathrm{kB}$, but not $80 \mathrm{kB}$. This result is consistent with the $933 \mathrm{~W}$ bacteriophage genome size of $61 \mathrm{kB}$. None of the 40 tetracycline-resistant recombinants were kanamycin-resistant, consistent with the transducing particles containing only host DNA.
Table 1. Transduction in enterohemorrhagic Escherichia coli.

\begin{tabular}{|lllll|}
\hline \multirow{2}{*}{ Selection } & \multicolumn{4}{c}{ Transductants per $\mathbf{1 0} \boldsymbol{\mu l}$ lysate } \\
\cline { 2 - 5 } & Plate 1 & Plate 2 & Plate 3 & Average \\
\hline $\mathrm{Lac}^{+}$ & 130 & 128 & 134 & 131 \\
\hline $\mathrm{Ara}^{+}$ & 72 & 71 & 73 & 73 \\
\hline $\mathrm{Mal}^{+}$ & 89 & 88 & 88 & 88 \\
\hline
\end{tabular}

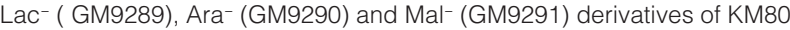
were transduced with a lysate prepared on GM9251. The number of transductants on each of three plates is shown followed by the average. There were no colonies on plates seeded with the recipient strain alone or from the GM9251 lysate.

Bacteriophage $933 \mathrm{~W}$ is a member of a family of stx-encoding bacteriophages and these may also be capable of transduction. The annotation of a terminase in the $933 \mathrm{~W}$ genome should be revised to a pacase to more clearly reflect the action of these enzymes. The ability of bacteriophage $933 \mathrm{~W}$ to transduce genetic markers in EHEC and E. coli $\mathrm{K}-12$ suggests that other related bacteria such as enteropathogenic E. coli or Citrobacter rhodentium may also be amenable to this type of genetic exchange. Only $933 \mathrm{~W}$ non-lysogens have been used in the present study as recipients and it is not yet known if $933 \mathrm{~W}$ lysogens can be transduced.

\section{Conclusion}

Bacteriophage $933 \mathrm{~W}$ is capable of transducing genetic markers in EHEC and E. coli $\mathrm{K}-12$.

\section{Author contributions}

MGM and AP conceived the study, designed and carried out the research and agreed to the final content, and wrote the paper.

\section{Competing interests}

No competing interests were disclosed.

\section{Grant information}

This work was supported by NIH grant GM063790 to MGM.

The funders had no role in study design, data collection and analysis, decision to publish, or preparation of the manuscript.
1. Donnenberg MS, Whittam TS: Pathogenesis and evolution of virulence in enteropathogenic and enterohemorrhagic Escherichia coli. J Clin Invest. 2001; 107(5): 539-548.

PubMed Abstract | Publisher Full Text | Free Full Text

2. Kaper JB, Nataro JP, Mobley HL: Pathogenic Escherichia coli. Nat Rev Microbiol. 2004; 2(2): 123-140.

PubMed Abstract | Publisher Full Text

3. Spears KJ, Roe AJ, Gally DL: A comparison of enteropathogenic and enterohaemorrhagic Escherichia coli pathogenesis. FEMS Microbiol Lett. 2006; 255(2): 187-202.

PubMed Abstract | Publisher Full Text
4. Tyler JS, Mills MJ, Friedman DI: The operator and early promoter region of the Shiga toxin type 2-encoding bacteriophage 933W and control of toxin expression. J Bacteriol. 2004; 186(22): 7670-7679. PubMed Abstract | Publisher Full Text | Free Full Text

5. Murphy KC: Use of bacteriophage lambda recombination functions to promote gene replacement in Escherichia coli. J Bacteriol. 1998; 180(8): 2063-2071.

PubMed Abstract | Free Full Text

6. Court DL, Sawitzke JA, Thomason LC: Genetic engineering using homologous recombination. Annu Rev Genet. 2002; 36: 361-388. PubMed Abstract | Publisher Full Text 
7. Ho TD, Waldor MK: Enterohemorrhagic Escherichia coli 0157: H7 gal mutants are sensitive to bacteriophage $\mathbf{P 1}$ and defective in intestinal colonization. Infect Immun. 2007; 75(4): 1661-1666.

PubMed Abstract | Publisher Full Text | Free Full Text

8. Perna NT, Plunkett G III, Burland V, et al.: Genome sequence of enterohaemorrhagic Escherichia coli 0157:H7. Nature. 2001; 409(6819): 529-533.

PubMed Abstract | Publisher Full Text

9. Plunkett G III, Rose DJ, Durfee TJ, et al:: Sequence of Shiga toxin 2 phage $933 \mathrm{~W}$ from Escherichia coli 0157:H7: Shiga toxin as a phage late-gene product. $J$ Bacteriol. 1999; 181(6): 1767-1778. PubMed Abstract | Free Full Text

10. Dewitt SK, Adelberg EA: The Occurrence of a Genetic Transposition in a Strain of Escherichia Coli. Genetics. 1962; 47(5): 577-585. PubMed Abstract | Free Full Text

11. Meselson M, Yuan R: DNA restriction enzyme from E. coli. Nature. 1968
217(5134): 1110-1114

PubMed Abstract

12. Shaw KJ, Berg CM: Escherichia coli K-12 auxotrophs induced by insertion of the transposable element Tn5. Genetics. 1979; 92(3): 741-747.

PubMed Abstract | Free Full Text

13. Kleckner N, Chan RK, Tye BK, et al:: Mutagenesis by insertion of a drugresistance element carrying an inverted repetition. $J$ Mol Biol. 1975; 97(4): 561-575.

PubMed Abstract

14. Nowosielska A, Marinus MG: DNA mismatch repair-induced double-strand breaks. DNA Repair. 2008; 7(1): 48-56.

PubMed Abstract | Publisher Full Text | Free Full Text

15. Murphy KC, Campellone KG: Lambda Red-mediated recombinogenic engineering of enterohemorrhagic and enteropathogenic E. coli. BMC Mol Biol. 2003; 4: 11.

PubMed Abstract | Publisher Full Text | Free Full Text 


\section{Open Peer Review}

\section{Current Peer Review Status:}

\section{Version 1}

Reviewer Report 21 January 2013

https://doi.org/10.5256/f1000research.303.r716

(C) 2013 Donnenberg M. This is an open access peer review report distributed under the terms of the Creative Commons Attribution License, which permits unrestricted use, distribution, and reproduction in any medium, provided the original work is properly cited.

\section{Michael Donnenberg}

School of Medicine, University of Maryland, Baltimore, MD, USA

The findings are novel and of potential interest in that generalized transduction, if confirmed in other pathogenic $E$. coli strains, could facilitate more rapid progress in understanding these infections. Such confirmation is necessary before its full impact can be appreciated.

Competing Interests: No competing interests were disclosed.

I confirm that I have read this submission and believe that I have an appropriate level of expertise to confirm that it is of an acceptable scientific standard.

Reviewer Report 16 January 2013

https://doi.org/10.5256/f1000research.303.r707

(C) 2013 Court D. This is an open access peer review report distributed under the terms of the Creative Commons Attribution License, which permits unrestricted use, distribution, and reproduction in any medium, provided the original work is properly cited.

\section{Donald Court}

Gene Regulation and Chromosome Biology Laboratory, Center for Cancer Research, National Cancer Institute, Frederick, MD, USA

This paper describes methods used for E. coli 0157:H7 (EHEC) to prepare phage lysates and to use those lysates for generalized transduction of bacterial markers, which is useful since P1 transduction in this strain requires the presence of a special gal mutant in any EHEC recipient. The general phage methods described are also useful. I have a few minor comments below to improve the paper.

- The authors point out that the kanR phage marker does not come along during the transduction 
event. See the last sentence of the abstract and the last sentence in the second paragraph of results. Both should say something to the effect that this indicates phage DNA is not involved instead of arguing that host DNA is. This is pretty obvious but I think the question is more whether there is some kind of host DNA pick into a phage genome.

- It would be informative if the authors can provide a frequency of generalized transductants per phage particle (as well as per 10 microliters). What is the frequency of lysogeniziation by this phage as measured by KanR? How does this transduction compare to a similar phage like P22.

- How frequently does the tet marker transduce the EHEC strain?

I mark this as approved for publication with some minor revisions as suggested.

Competing Interests: No competing interests were disclosed.

\section{I confirm that I have read this submission and believe that I have an appropriate level of expertise to confirm that it is of an acceptable scientific standard.}

Reviewer Report 14 January 2013

https://doi.org/10.5256/f1000research.303.r705

(C) 2013 Wade J. This is an open access peer review report distributed under the terms of the Creative Commons Attribution License, which permits unrestricted use, distribution, and reproduction in any medium, provided the original work is properly cited.

\section{Joe Wade \\ Wadsworth Center, New York State Department of Health, Albany, NY, USA}

The authors describe a new transduction system for E. coli 0157:H7, a strain that cannot be transduced using P1. Such a transducing phage would be a useful tool. The authors make a fairly convincing case that they have indeed isolated a transducing phage. However, there are some important, missing controls, and the efficiency of co-transduction of linked genes needs to be discussed in greater detail.

Specific comments:

1. Given that the impact of the transducing phage is likely to be limited to $0157: H 7$ strains (i.e. not K12), it is important to demonstrate transduction in 0157:H7 more convincingly. Specifically, the authors should identify the specific mutation in the recipient strain and then show that this mutation is lost in the transductants. This will rule out spontaneous mutations as the cause of the phenotype. Alternatively, and perhaps more easily, the authors could attempt to transduce an antibiotic resistance gene, as they did for $\mathrm{K}-12$.

2. The authors show that co-transduction occurs in $\mathrm{K}-12$ between genes $14 \mathrm{~kb}$ apart. The frequency of co-transduction is $100 \%$ for 40 colonies tested. This is higher than I would have expected. Assuming random acquisition of host DNA by the phage, you would expect 8 or 9 colonies, on average, in which the two genes did not co-transduce. The probability of getting 40 out of 40 cotransductants would be $3 \mathrm{e}^{-5}$. This suggests that the phage does not package host DNA randomly. 
The authors should discuss the significance of this, especially in light of the utility of the phage for generalised transduction.

Competing Interests: No competing interests were disclosed.

I confirm that I have read this submission and believe that I have an appropriate level of expertise to confirm that it is of an acceptable scientific standard, however I have significant reservations, as outlined above.

Author Response ( F1000Research Advisory Board Member ) 07 May 2013

Martin Marinus, University of Massachusetts Medical School, Worcester MA, USA

1. There were never any colonies on the control plates for the $\mathrm{O} 157: \mathrm{H} 7$ transductions for three different markers so we consider the possibility that the transductants are spontaneous revertants to be very low.

2. We agree with the reviewer on this point and it is very possible that the DNA is not packaged randomly.

Competing Interests: We have no competing interests

\section{Comments on this article}

\section{Version 1}

Author Response ( F1000Research Advisory Board Member ) 07 May 2013

Martin Marinus, University of Massachusetts Medical School, Worcester MA, USA

We have now shown that a 933W lysogen can be transduced. Specifically, we transduced E. coli K-12 AB1157 and AB1157 (933W) strains to prototophy for Leu+, Pro+, His+ and Arg+. The frequency of transduction of the lysogen was about $80 \%$ that of the non-lysogen for all markers.

Competing Interests: We have no competing interests 
The benefits of publishing with F1000Research:

- Your article is published within days, with no editorial bias

- You can publish traditional articles, null/negative results, case reports, data notes and more

- The peer review process is transparent and collaborative

- Your article is indexed in PubMed after passing peer review

- Dedicated customer support at every stage

For pre-submission enquiries, contact research@f1000.com 